\title{
CARBON DIOXIDE AND METHANE EMISSIONS FROM A TEMPERATE SALT MARSH TIDAL CREEK
}

\author{
by
}

Branimir Trifunovic

A thesis submitted to the Faculty of the University of Delaware in partial fulfillment of the requirements for the degree of Master of Science in Water Science and Policy

Fall 2019

(C) 2019 Branimir Trifunovic

All Rights Reserved 


\section{CARBON DIOXIDE AND METHANE EMISSIONS FROM A TEMPERATE SALT MARSH TIDAL CREEK}

by

Branimir Trifunovic

Approved:

Rodrigo Vargas, Ph.D.

Professor in charge of thesis on behalf of the Advisory Committee

Approved:

Erik H. Ervin, Ph.D.

Chair of the Department of Plant and Soil Sciences

Approved:

Mark W. Rieger, Ph.D.

Dean of the College of Agriculture and Natural Resources

Approved:

Douglas J. Doren, Ph.D.

Interim Vice Provost for Graduate and Professional Education and Dean of the Graduate College 


\section{ACKNOWLEDGMENTS}

I would like to thank my advisor, Dr. Rodrigo Vargas, my committee

members, Dr. Angelia Seyfferth and Dr. Carlos Moffat, and two of my labmates, Margaret Capooci and Alma Vazquez-Lule, for their help in bringing this manuscript to life.

My partner, Lauren Mosesso, our dog Jade, my parents, Dusica and Misko, and my brother, Bogdan, were instrumental in their support for me over the last two years.

I would like to dedicate this manuscript to my grandmother Natalija, who recently passed away. She would have been proud to see this accomplishment.

I would also like to thank Kari Saint-Laurent and Mike Mensinger for their support of our work at the study site; and Daniel Warner, Josep Barba, and Ricardo Llamas for their help in collecting manual greenhouse gas flux measurements. This study would also not be possible without financial support by NSF Grant \#1652594. So, if you pay your taxes, thank you! 


\section{TABLE OF CONTENTS}

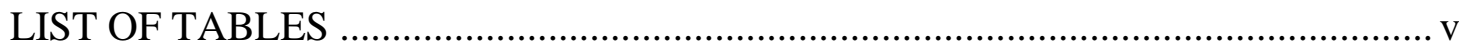

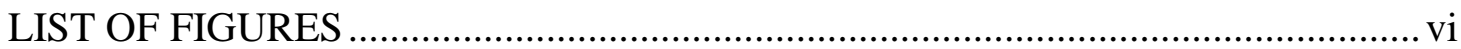

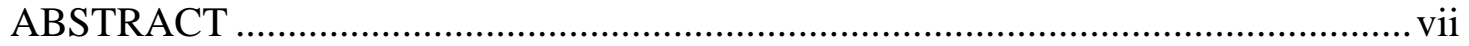

Chapter

1 CARBON DIOXIDE AND METHANE EMISSIONS FROM A

TEMPERATE SALT MARSH TIDAL CREEK ………………....................... 1

Introduction ...................................................................................... 1

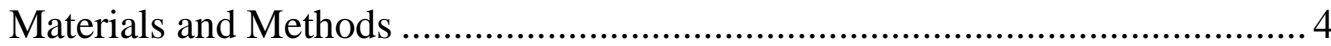

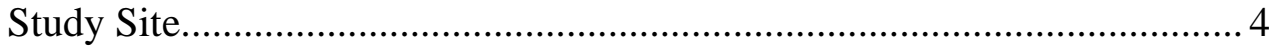

Plant Phenological Stages........................................................................ 5

Creek $\mathrm{CO}_{2}$ and $\mathrm{CH}_{4}$ Fluxes .............................................................. 6

Water-to-Atmosphere Flux Model ........................................................... 7

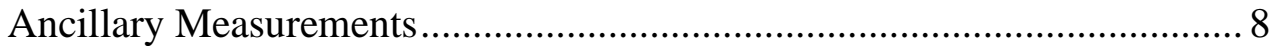

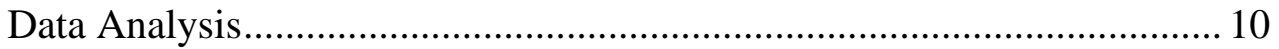

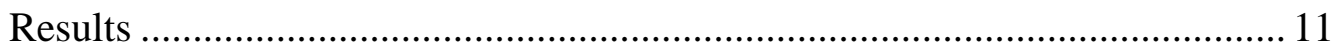

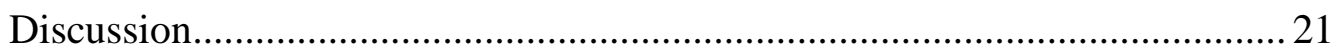

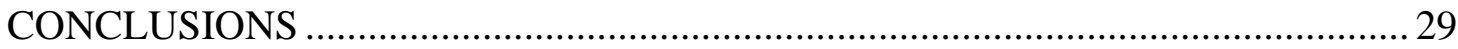

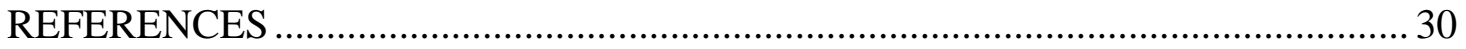




\section{LIST OF TABLES}

Table 1 Gas Transfer Velocities $(\mathrm{k})$ of $\mathrm{CO}_{2}$ and $\mathrm{CH}_{4}$ by Tide Stage .................. 14 


\section{LIST OF FIGURES}

Figure 1 Time series of daily averages of selected environmental variables.. ...... 12

Figure 2 Boxplots comparing modeled and measured efflux of $\mathrm{CO}_{2}$ and $\mathrm{CH}_{4}$ divided by tide stage.

Figure 3 Time series of daily averages of creek $\mathrm{pCO}_{2}, \mathrm{pCH}_{4}$, modelled $\mathrm{CO}_{2}$ efflux, and modelled $\mathrm{CH}_{4}$ efflux.

Figure 4 Box plots comparing $\mathrm{CO}_{2}$ concentration or modelled $\mathrm{CO}_{2}$ efflux between tide stages for each phenophase.

Figure 5 Box plots comparing $\mathrm{CH}_{4}$ concentration or modelled $\mathrm{CH}_{4}$ efflux between tide stages for each phenophase

Figure 6 Results of a canonical correlation analysis between measured environmental variables and modelled creek $\mathrm{CO}_{2}$ and $\mathrm{CH}_{4}$ efflux 19

Figure 7 Box plots comparing ecosystem-scale nighttime $\mathrm{CO}_{2}$ efflux, creek nighttime $\mathrm{CO}_{2}$ efflux, and nighttime sediment $\mathrm{CO}_{2}$ efflux along with box plots comparing ecosystem-scale and creek $\mathrm{CH}_{4}$ fluxes 


\begin{abstract}
Coastal salt marshes store large amounts of carbon but the magnitude and patterns of greenhouse gas (GHGs; including $\mathrm{CO} 2$ and $\mathrm{CH} 4$ ) fluxes are unclear. Information about GHG fluxes from these ecosystems mainly comes from studies of sediments or at the ecosystem-scale (using eddy covariance), but fluxes from tidal creeks are currently unknown. We measured GHG concentrations in water, water quality, meteorology, sediment $\mathrm{CO} 2$ efflux, ecosystem-scale GHG fluxes, and plant phenology; all at half-hour time-steps over one year. Manual creek GHG flux measurements were used to parameterize a model of water-to-atmosphere GHG fluxes. The creek was a source of GHGs to the atmosphere where tidal patterns rather than water temperature controlled diel variability. Dissolved oxygen and wind speed were inversely correlated with creek CH4 efflux. Despite lacking a seasonal pattern, creek $\mathrm{CO} 2$ efflux was correlated with drivers such as turbidity across phenological phases. Overall, night-time creek CO2 efflux $(3.6 \pm 0.63 \mu \mathrm{mol} / \mathrm{m} 2 / \mathrm{s})$ was over two times higher than night-time marsh sediment CO2 efflux $(1.5 \pm 1.23 \mu \mathrm{mol} / \mathrm{m} 2 / \mathrm{s})$. Creek CH4 efflux $(17.5 \pm 6.9 \mathrm{nmol} / \mathrm{m} 2 / \mathrm{s})$ was four times lower than ecosystem-scale CH4 fluxes $(68.1 \pm 52.3 \mathrm{nmol} / \mathrm{m} 2 / \mathrm{s})$ across the year. These results suggest that salt marsh tidal creeks are potential hotspots for $\mathrm{CO} 2$ emissions and (because they are supersaturated with $\mathrm{CH} 4$; up to $>6000 \mu \mathrm{mol} / \mathrm{mol}$ ) could contribute to lateral transport of $\mathrm{CH} 4$ to the coastal ocean. This study provides insights for modelling GHG efflux from tidal creeks and suggests that changes in tide stage overshadows water temperature in determining magnitudes of fluxes.
\end{abstract}




\section{Chapter 1}

\section{CARBON DIOXIDE AND METHANE EMISSIONS FROM A TEMPERATE SALT MARSH TIDAL CREEK}

\section{Introduction}

Coastal salt marshes are becoming increasingly of interest to carbon cycle science due to the large amounts of carbon sequestered in their sediments (Howard et al., 2017). These systems are disproportionately important to the global carbon cycle relative to their small global area $\left(22,000-400,000 \mathrm{~km}^{2}\right)$; on average they store 10 times more carbon per unit area than terrestrial forests (McLeod et al., 2011). However, stored carbon is vulnerable to increased erosion and decomposition due to sea level rise (Jones et al., 2018; Ruiz-Fernández et al., 2018), habitat disturbance from land cover change and seagrass accumulation, (Macreadie et al., 2013; Pendleton et al., 2012), and increased heterotrophic respiration due to rising temperatures (BondLamberty et al., 2018; Kirwan et al., 2014). The vulnerability of these large carbon stocks requires detailed research into the magnitudes, patterns, and drivers of carbon exchange across different landscape features in salt marshes.

Coastal salt marshes are hotspots for carbon storage because they are sub-toanoxic, which decreases the rate of heterotrophic decomposition of soil organic carbon (SOC). In wet sediments, limited oxygen supply drives anaerobic metabolism by soil microbes, which lowers $\mathrm{CO}_{2}$ emissions compared to upland terrestrial environments 
where aerobic metabolism dominates (Greenwood, 1961; Raich \& Schlesinger, 1992). Moreover, sulfate-reducing bacteria compete with methanogens for substrate, thereby lowering $\mathrm{CH}_{4}$ production (Tobias \& Neubauer, 2009). The slow rate of carbon oxidation in marsh sediments thus results in large accumulations of SOC within these ecosystems (Chmura et al., 2003). However, there is a delicate balance between anaerobic and aerobic conditions in these tidal systems due to the tidal ebb and flood, which changes the redox conditions of the sediments near tidal channels (Baumann et al., 2015). These dynamic conditions could promote emissions of $\mathrm{CO}_{2}$ and $\mathrm{CH}_{4}$ from the land surface and water-to-atmosphere via changes in oxygen concentrations and redox oscillations (Moseman-Valtierra, 2012). Therefore, understanding the patterns and drivers of salt marsh greenhouse gas $\left(\mathrm{GHG}\right.$; i.e., $\mathrm{CO}_{2}$ and $\left.\mathrm{CH}_{4}\right)$ efflux is important to understand how SOC in salt marshes will respond to weather variability and global environmental change.

The majority of salt marsh GHG efflux studies have focused on soils/sediment (Chmura et al., 2011, 2016; Tong et al., 2010, 2013; Capooci et al., 2019) or used eddy covariance towers at ecosystem-scale (Forbrich et al., 2015, 2018; Moffett et al., 2010), but the dynamics of GHG efflux from tidal creeks are currently unknown. Past studies on soil GHG fluxes revealed that tidal patterns play an important role in GHG dynamics in these ecosystems. These tidal patterns affect both $\mathrm{CO}_{2}$ (Huertas et al., 2017) and $\mathrm{CH}_{4}$ emissions (Tong et al., 2010) by increasing the aerobic zone in the sediment profile near tidal creeks with the ebbing tide and decreasing the aerobic zone with the flooding tide. Tides also affect the conditions for GHG efflux by moving 
sediments, organic matter, and nutrients into and out of the marsh (Fagherazzi et al., 2013). Despite the knowledge of tides as an important GHG efflux control, to our knowledge there have been no studies of GHG efflux directly from marsh tidal channels or creeks. These landscape features have been shown to be important sources of dissolved inorganic carbon to estuaries (Neubauer \& Anderson, 2003; Wang \& Cai, 2004; Wang et al., 2016), and may be important contributors of $\mathrm{CH}_{4}$ and $\mathrm{CO}_{2}$ efflux in marsh ecosystems.

Previous studies on GHG efflux from terrestrial streams, mangrove tidal creeks, and coastal rivers found that flowing waters have high GHG efflux and suggest that GHG efflux from salt marsh creeks could be higher per unit area than the surrounding landscape (Call et al., 2015; Lauerwald et al. 2009; Linto et al., 2014; Raymond et al., 2013; Yang et al., 2017). Therefore, our overarching goal was to characterize the temporal dynamics and magnitudes of $\mathrm{CO}_{2}$ and $\mathrm{CH}_{4}$ efflux from a temperate salt marsh tidal creek. In particular, we aimed to a) measure the temporal patterns and magnitudes of $\mathrm{CO}_{2}$ and $\mathrm{CH}_{4}$ efflux from a salt marsh creek; b) identify the biophysical drivers for $\mathrm{CO}_{2}$ and $\mathrm{CH}_{4}$ efflux throughout the year; and c) determine how the magnitudes of $\mathrm{CO}_{2}$ and $\mathrm{CH}_{4}$ efflux compare to those from sediments and at the ecosystem-scale.

We explored four interrelated hypotheses: First, we hypothesized that creek GHG emissions would be higher in the summer due to the temperature dependence of heterotrophic respiration (Zhong et al., 2013) and methanogenesis (Yvon-Durocher et al., 2014). Second, water-to-atmosphere GHG efflux would be highest during ebb and 
flood tides as the water is moving faster than compared to the low flows at high and low tides. This hypothesis is supported by the fact that faster water velocity usually has a higher gas transfer velocity (Raymond et al., 2012). Third, dissolved oxygen and salinity are likely negative controls on $\mathrm{CH}_{4}$ emissions due to their inhibiting effect on methanogenesis (Poffenbarger et al., 2011; Tobias \& Neubauer, 2009). Fourth, the creek's $\mathrm{CO}_{2}$ emissions (per unit area) could be higher than the surrounding soil emissions because of the high GHG efflux potential of flowing waters (Lauerwald et al., 2009; Linto et al., 2014). We addressed this research by taking advantage of automated measurements of $\mathrm{CO}_{2}$ and $\mathrm{CH}_{4}$ concentrations (alongside a wide array of ancillary information) which provided unprecedented information about temporal patterns of GHG emissions in tidal salt marshes.

\section{Materials and Methods}

Study Site

This study was carried out in the St. Jones Reserve, a component of the Delaware National Estuarine Research Reserve in Dover, Delaware, U.S.A. The study site is part of the AmeriFlux (site ID: US-StJ) and Phenocam (site ID: stjones) networks The GHG concentration and efflux sampling location was located at Aspen Landing within a microtidal (mean tide range of $1.5 \mathrm{~m}$ ), mesohaline (typical salinity of 5-18 ppt) salt marsh (DNREC, 2006) tidal creek. Spartina alterniflora is the dominant plant species, making up $62.2 \%$ of the marsh's land cover with the invasive 
Phragmites australis representing 13.4\% (DNREC, 2006). The reserve is located on the Atlantic Coastal Plain geologic unit (DNREC, 2006) and made up of $40 \%$ Transquaking and 40\% Mispillon soils consisting of layers of mucky peat, muck, mucky silt loam, and silt loam (USDA, 2019). The climate is temperate with four distinct seasons and an average maximum July temperature of $31.7^{\circ} \mathrm{C}$ and an average minimum January temperature of $4.4{ }^{\circ} \mathrm{C}$ (DNREC, 2006). Average precipitation is $117 \mathrm{~cm} / \mathrm{yr}$ with an average snowfall of $40 \mathrm{~cm} / \mathrm{year}$ (DNREC, 2006).

\section{Plant Phenological Stages}

The phenological stages were identified using the greenness index (GI), a vegetation index derived from a time lapse of RGB photographs of vegetation cover that quantifies the number of green pixels relative to the overall brightness (Gillespie et al., 1987). The study site follows the PhenoCam network's protocol for data collection, storage and processing (Seyednasrollah et al., 2019). A NetCam SC camera (StarDot Technologies, Buena Vista, CA, USA) took RGB photographs every half hour, and we identified a region of interest (ROI) adjacent to the creek. The ROI was represented mainly by $S$. cynosuroides with some S. alterniflora. Phenocam data was analyzed from March $3^{\text {rd }}, 2017$ to December $13^{\text {th }}, 2017$. Phenology data was revised, analyzed, and divided into phenophases using the Phenopix R package (Filippa et al., 2016). Data revision consisted of calculating the daily averages of the greenness index and filtering out images that were too dark. Four distinct phenophases were identified 
based on the greenness index: a) Dormant for when the plants were inactive during winter; b) Greenup for when the plants were initially growing following the Dormant phenophase; c) Maturity for when the plants reached a peak in greenness; and d) Senescence for when the plants started losing greenness as they moved into the Dormant phenophase.

\section{Creek $\mathrm{CO}_{2}$ and $\mathrm{CH}_{4}$ Fluxes}

The concentrations of $\mathrm{CO}_{2}\left(\mathrm{pCO}_{2}\right)$ and $\mathrm{CH}_{4}\left(\mathrm{pCH}_{4}\right)$ within the water of the creek were measured from March $3^{\text {rd }}, 2017$ to December $13^{\text {th }}, 2017$ using an eosGP $\mathrm{CO}_{2}$ Concentration Probe (Eosense, Dartmouth, NS, Canada) and a Mini-Pro $\mathrm{CH}_{4}$ Probe (Pro Oceanus, Bridgewater, NS, Canada), respectively. Data were collected every minute, corrected for changes in pressure and temperature, and averaged into 30-minute intervals. Probes were cleaned with deionized water every two weeks to prevent sediment accumulation and biofilm build-up in the sensor membranes.

Manual measurements of $\mathrm{CO}_{2}$ and $\mathrm{CH}_{4}$ efflux from the creek were taken every two weeks from September 2017 to December 2017 along with four 24-hour sampling campaigns (two neap tides; 9/1/17, 11/9/17, two spring tides; 9/18/17, 11/3/17) to capture tidal diel patterns. Each campaign sampled over the course of two tidal cycles, with measurements at low, flood, high, and ebb tide, for a total of eight measurements. A closed-system floating flux chamber (20 cm in diameter; Rawitch, 2016) was coupled with an Ultraportable Greenhouse Gas Analyzer (Los Gatos Research, Santa 
Clara, CA, USA) for flux measurements. Each manual measurement lasted 3 minutes to allow the gases to accumulate and the change in concentration within the chamber was recorded every two seconds. Creek GHG effluxes were calculated with a linear equation using the change in gas concentration over time, chamber volume and area, atmospheric pressure, water temperature, and the ideal gas law constant as described in previous studies (Pearson et al., 2016; Warner et al., 2017). Three consecutive manual measurements were taken and averaged to represent one measurement in time for subsequent analyses. A total of 38 averaged measurements were recorded and included in the final model calibration.

\section{Water-to-Atmosphere Flux Model}

Automatic concentrations and manual flux measurements of each GHG were used with Equations 1 and 2 to build a model of water-to-atmosphere GHG efflux from the tidal creek. First, the gas transfer velocity was calculated as:

$$
\boldsymbol{k}=\frac{\Delta p G a s}{\text { fGas }(\text { measured })}
$$

where $k$ is the gas transfer velocity, $\triangle p G a s$ is the difference between the concentrations of the GHG of interest in the water and the atmosphere, and fGas(measured) is the measured flux (from manual measurements) of the GHG of interest. For each GHG, a $k$ was calculated for each of the four tide stages using the 
mean of all measurements taken at each tide stage. Then fGas(modelled), representing the predicted GHG efflux, was calculated as:

$$
\text { fGas }(\text { modelled })=k * \Delta p G a s
$$

where $k$ is the gas transfer velocity for a specific tidal stage, and $\triangle p G a s$ is the difference between the concentrations of the GHG of interest in the water and the concentration of the GHG in the atmosphere for a specific tidal stage (associated with the respective $k$ ). These equations are a modification of Fick's Law with the addition of $k$, which takes into account the diffusivity of the gas along with the effects of physical processes like turbulence and water speed (Matthews, 1999).

Tide stages were defined as low, flood, high, and ebb. Low tide was defined as the half-hour before and after the local minima of the water level, while high tide used the local maxima. Each local minima and maxima were calculated using the Tides package in R (Cox \& Schepers, 2017). Flood tide was assigned to all measurements taken after low tide but before high tide, and ebb tide was assigned to all measurements taken after high tide but before low tide.

\section{Ancillary Measurements}

Ecosystem-scale $\mathrm{CO}_{2}$ and $\mathrm{CH}_{4}$ fluxes were measured by the Eddy Covariance (EC) technique. The EC tower is equipped with a WindMaster Pro anemometer, 
model 160724 (Gill Instruments, Lymington, Hamisphere, UK), a LI-7200RS

enclosed path $\mathrm{CO}_{2} / \mathrm{H}_{2} \mathrm{O}$ Analyzer and a LI-7700 open path $\mathrm{CH}_{4}$ analyzer, both sensors from LI-COR (LI-COR Environmental, Lincoln, NE, USA). All data were collected at $10 \mathrm{~Hz}$, processed in EddyPro 6.2.0 Software from LI-COR (LI-COR Environmental, Lincoln, NE, USA) and corrected for potential misalignments of the anemometer, turbulence fluctuations, and air density fluctuations following AmeriFlux protocols. For this study we used nighttime net ecosystem exchange (NEE) as a representation of ecosystem respiration (Mahecha et al., 2010) but all available data for ecosystem-scale $\mathrm{CH}_{4}$ fluxes.

Soil $\mathrm{CO}_{2}$ fluxes were measured every 5 minutes with the eosFD Soil $\mathrm{CO}_{2}$ Flux Sensor (Eosense, Dartmouth, NS, Canada) at two different locations - approximately 13 and $51 \mathrm{~m}$ from the creek bank. The measurements from both chambers were averaged together for all analyses. The eosFD uses forced diffusion to regulate gas flow through a diffusive membrane rather than a more traditional mechanical pump, as seen in other closed chamber set-ups (Risk et al., 2011). The water quality parameters (measured in 15 min intervals) of temperature, salinity, water level, turbidity, and dissolved oxygen were measured with a YSI 6600 sonde (YSI Inc., Yellow Springs, $\mathrm{OH}$, USA) The weather parameters (measured in 15 minute intervals) of barometric pressure, wind speed, total photosynthetically active radiation, and total precipitation, were measured with a CR1000 Meteorological Monitoring Station (Campbell Scientific, Logan, UT, USA). Both the water quality and weather parameters followed the Centralized Data Management Protocol from the National Estuarine Research 
Reserve System (NERRS) (NERRS, 2015) and are available online (https://cdmo.baruch.sc.edu/). All measurements underwent QA/QC (e.g., check for outliers, data inconsistencies) and were averaged into 30 minute and daily averages for further data analysis.

\section{Data Analysis}

All data was processed and analyzed using R 3.4.3 (R Foundation for Statistical Computing, Vienna, Austria). Nonparametric Kruskal-Wallis tests followed by Dunn post-hoc tests were used for all analyses involving manual GHG flux data. Parametric ANOVA tests followed by Tukey HSD post-hoc tests were used for all other analyses.

A canonical correlation analysis (CCA) using the R CCA package (González \& Déjean, 2012) was performed on daily averages to test the influence of various independent variables on the dependent variables of creek $\mathrm{CO}_{2}$ and $\mathrm{CH}_{4}$ efflux. One CCA was performed using all available data and one was carried out for each phenophase, making for a total of 5 separate analyses. The CCA method was chosen as the correlation between $\mathrm{CO}_{2}$ and $\mathrm{CH}_{4}$ effluxes can be examined, unlike with two separate multiple linear regressions (Thomas, 1984). This was necessary to determine how the selected drivers may affect only one or both GHGs.

The independent variables consisted of temperature, salinity, water level, turbidity, dissolved oxygen, barometric pressure, wind speed, total photosynthetically 
active radiation, and total precipitation. The CCA reduced all the independent variables to one independent canonical variate, and all the dependent variables to one dependent canonical variate (Thomas, 1984). The relationship between all the independent and dependent variables was represented by a linear correlation coefficient calculated between the independent canonical variate and the dependent canonical variate. The contribution of each variable to that overall correlation was represented by the linear correlation coefficient calculated between that variable and its' respective variate.

\section{Results}

Daily averages of ancillary measurements from March to December were typical of a Mid-Atlantic tidal salt marsh (Figure 1). The greenness index (GI, unitless; $0.34 \pm 0.02)$ peaked on DOY $219(0.40 ; 08 / 07 / 17)$ with an initial Dormant phase of 116 days, a Greenup phenophase of 74 days, a short Maturity phenophase of 32 days, a Senescence phenophase of 78 days, and a second Dormant phenophase of 65 days (Figure 1a). Water temperature (Figure $1 \mathrm{~b} ; 17.6 \pm 6.87^{\circ} \mathrm{C}$ ) and GI roughly followed the same seasonal pattern while dissolved oxygen (Figure 1c; $4.62 \pm 1.71 \mathrm{mg} / \mathrm{l}$ ) showed an inverse pattern of being lowest in July $(0.36 \mathrm{mg} / \mathrm{l})$ when temperature $(29.52$ ${ }^{\circ} \mathrm{C}$ ) and GI (0.40) were highest. Other measured variables did not show a seasonal pattern, despite having differences among phenophases. Water level (Figure 1e; 0.28 $\mathrm{m} \pm 0.12$ above sea level), wind speed (Figure $1 \mathrm{~d} ; 1.9 \pm 0.89 \mathrm{~m} / \mathrm{s}$ ), and salinity (Figure 
1f; $10.0 \pm 3.54 \mathrm{ppt}$ ) were dominated by shorter period variability (days to weeks) pattern. Salinity did tend to increase slowly during the first half of the record, but no clear seasonal cycle was discernible.

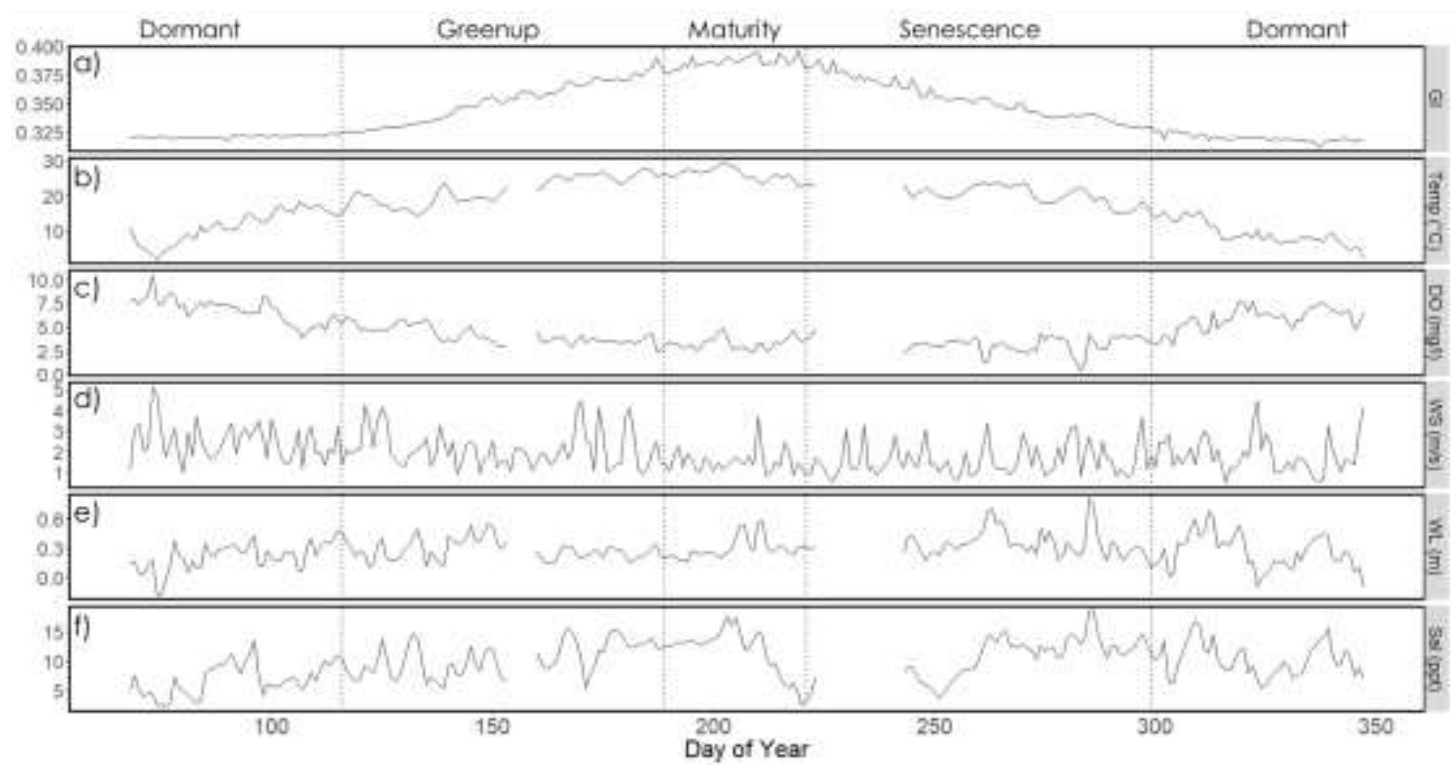

Figure 1 Time series of daily averages of greenness index (a), water temperature (b), dissolved oxygen (c), wind speed (d), water level above sea level (e), and salinity (f) during 2017. The time series are divided into Dormant, Greenup, Maturity, and Senescence phenophases marked by vertical dotted lines. 
Modelled creek GHG efflux was tested against the corresponding manual measurements. There were no statistically significant differences between means of modelled $\left(\mathrm{CO}_{2} ; 3.88 \pm 2.52 \mu \mathrm{mol} / \mathrm{m}^{2} / \mathrm{s}, \mathrm{CH}_{4} ; 25.4 \pm 21.6 \mathrm{nmol} / \mathrm{m}^{2} / \mathrm{s}\right)$ and manual measurements $\left(\mathrm{CO}_{2} ; 4.11 \pm 4.51 \mu \mathrm{mol} / \mathrm{m}^{2} / \mathrm{s}, \mathrm{CH}_{4} ; 28.71 \pm 31.93 \mathrm{nmol} / \mathrm{m}^{2} / \mathrm{s}\right)$ overall (i.e., all available measurements) and when analyzed for each tide stage (KruskalWallis test; $\mathrm{p}>0.05$; Figure 2), but manual measurements had a larger range $\left(\mathrm{CO}_{2}\right.$; $\left.0.26-20.1 \mu \mathrm{mol} / \mathrm{m}^{2} / \mathrm{s}, \mathrm{CH}_{4} ; 1.3-123 \mathrm{nmol} / \mathrm{m} 2 / \mathrm{s}\right)$ than modelled values $\left(\mathrm{CO}_{2} ; 0.53-8.0\right.$ $\left.\mu \mathrm{mol} / \mathrm{m}^{2} / \mathrm{s}, \mathrm{CH}_{4} ; 2.05-66.9 \mathrm{nmol} / \mathrm{m}^{2} / \mathrm{s}\right)$. The magnitude of both manual and modelled GHG fluxes decreased in the order low tide $>$ ebb tide $>$ flood tide $>$ high tide (Kruskal-Wallis test; $p<0.05$; Figure 2). Gas transfer velocities followed the same tidal pattern and were generally two orders of magnitude smaller for $\mathrm{CH}_{4}$ (Table 1).
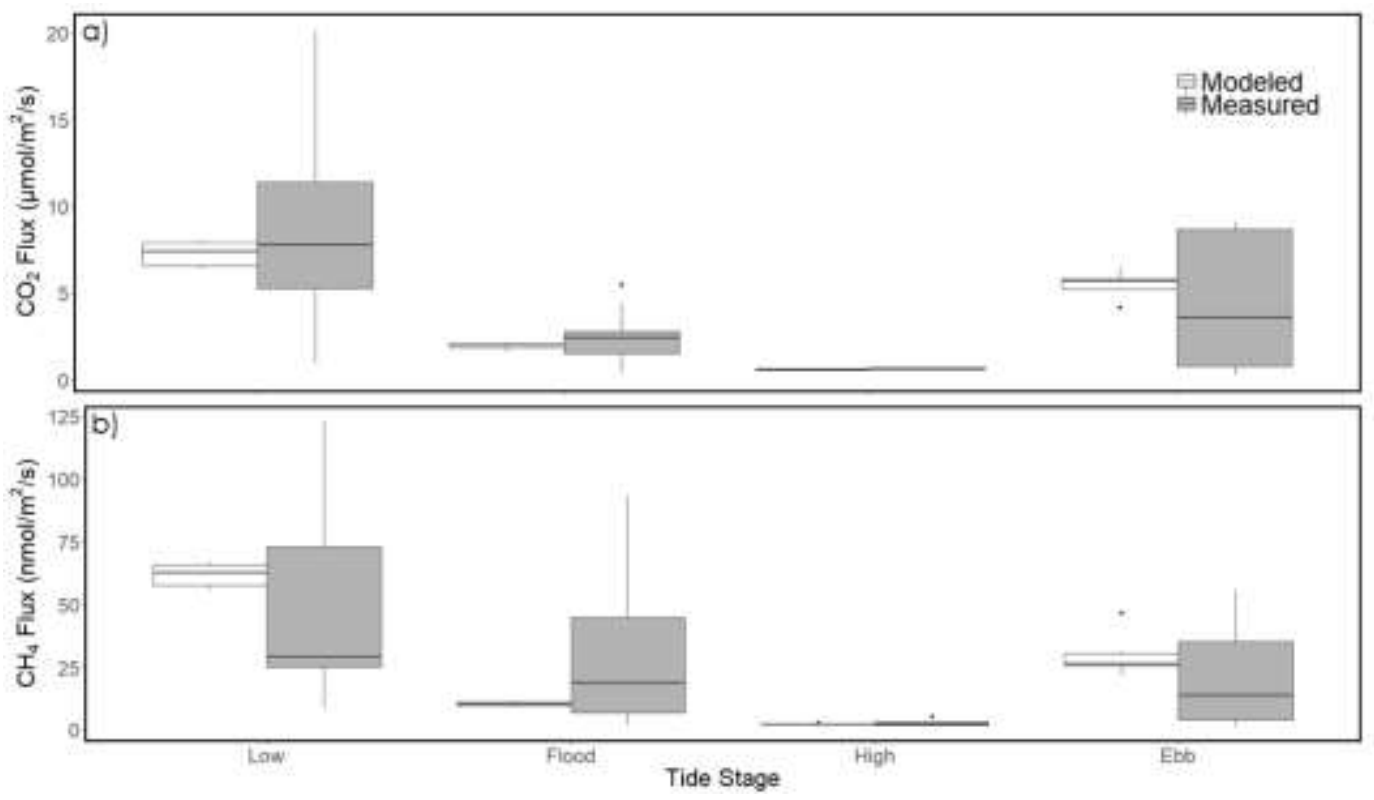
Figure 2 Boxplots comparing modeled and measured efflux of $\mathrm{CO}_{2}$ (a) and $\mathrm{CH}_{4}$ (b) divided by tide stage. All box plots by tide stage were significantly different from each other $(\mathrm{p}<0.05)$ while there were no statistically significant differences between modelled and measured efflux within each tidal stage $(\mathrm{p}>0.05)$.

Table 1 Gas Transfer Velocities (k) of $\mathrm{CO}_{2}$ and $\mathrm{CH}_{4}$ by Tide Stage GHG High Tide $k \quad$ Low Tide $k \quad$ Ebb Tide $k \quad$ Flood Tide $k$ $(\mathrm{m} / \mathrm{s}) \quad(\mathrm{m} / \mathrm{s}) \quad(\mathrm{m} / \mathrm{s}) \quad(\mathrm{m} / \mathrm{s})$

\begin{tabular}{ccccc}
\hline $\mathrm{CO}_{2}$ & 0.138 & 1.67 & 1.41 & 0.465 \\
$\mathrm{CH}_{4}$ & 0.002 & 0.0506 & 0.0227 & 0.00814 \\
\hline
\end{tabular}

Daily averages of $\mathrm{pCO}_{2}$ in the creek $(8729 \pm 622.2 \mu \mathrm{mol} / \mathrm{mol})$ exhibited a seasonal trend with a peak in the Maturity phenophase (Figure 3a). Half-hourly averages of creek $\mathrm{pCO}_{2}$ were highest at low tide $(9110 \pm 810 \mu \mathrm{mol} / \mathrm{mol})$, lowest at high tide $(8410 \pm 776 \mu \mathrm{mol} / \mathrm{mol})$, and roughly equal between flood $(8730 \pm 805)$ and ebb tides $(8690 \pm 780 \mu \mathrm{mol} / \mathrm{mol})$ (Figure 4a-d). Daily averages of modelled creek $\mathrm{CO}_{2}$ efflux $\left(3.7 \pm 0.63 \mu \mathrm{mol} / \mathrm{m}^{2} / \mathrm{s}\right)$, however, did not show a clear seasonal trend (Fig 3b). Half-hourly averages of modelled creek $\mathrm{CO}_{2}$ efflux consistently showed higher variability at low tide $\left(7.32 \pm 0.52 \mu \mathrm{mol} / \mathrm{m}^{2} / \mathrm{s}\right)$ than at high tide $(0.56 \pm 0.04$ $\mu \mathrm{mol} / \mathrm{m}^{2} / \mathrm{s}$ ) (Figure $\left.4 \mathrm{e}-\mathrm{h}\right)$. 

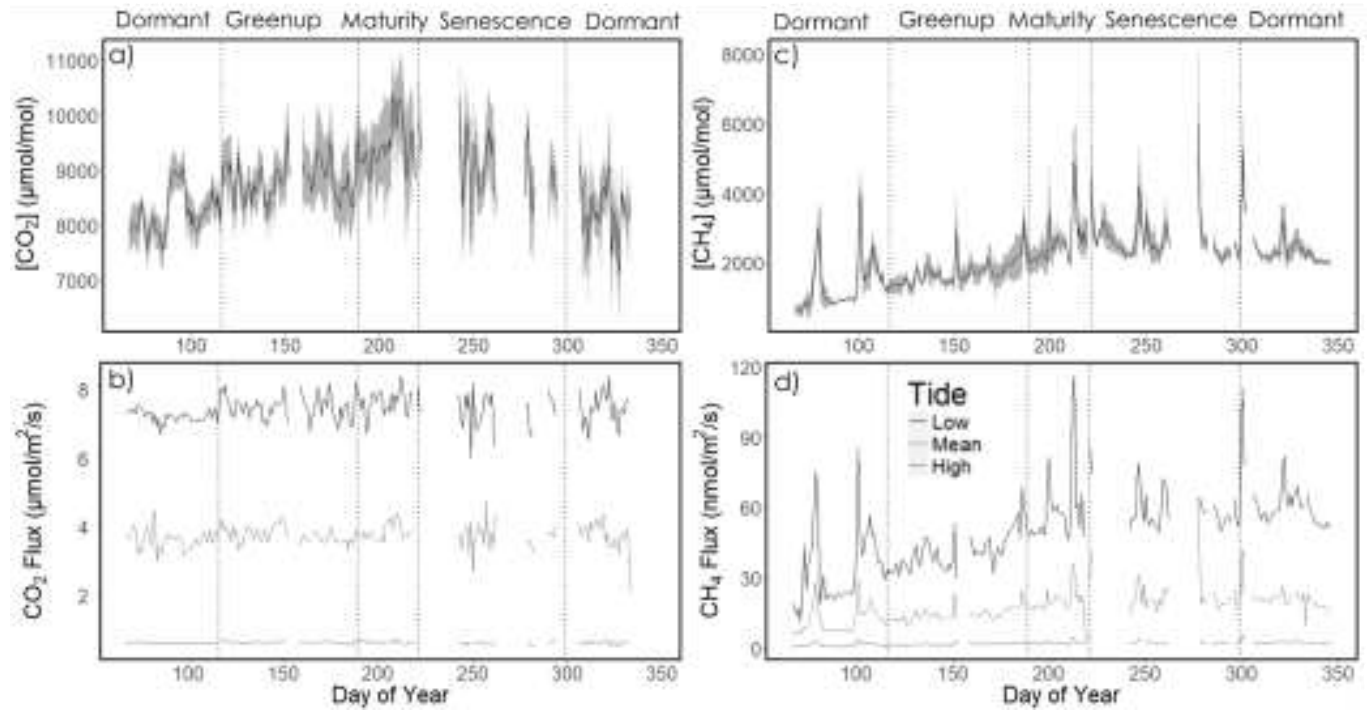

Figure 3 Time series of daily averages of creek $\mathrm{pCO}_{2}$ (a) and $\mathrm{pCH}_{4}$ (c). Time series of modelled $\mathrm{CO}_{2}$ efflux (b) and modelled $\mathrm{CH}_{4}$ efflux (d) divided into daily averages for high and low tide values, and a daily mean calculated with all available data. The grey area (in a and c) represents the $95 \%$ confidence intervals for the daily average. The time series are divided by phenophase into Dormant, Greenup, Maturity, and Senescence phenophases marked by vertical dotted lines. 

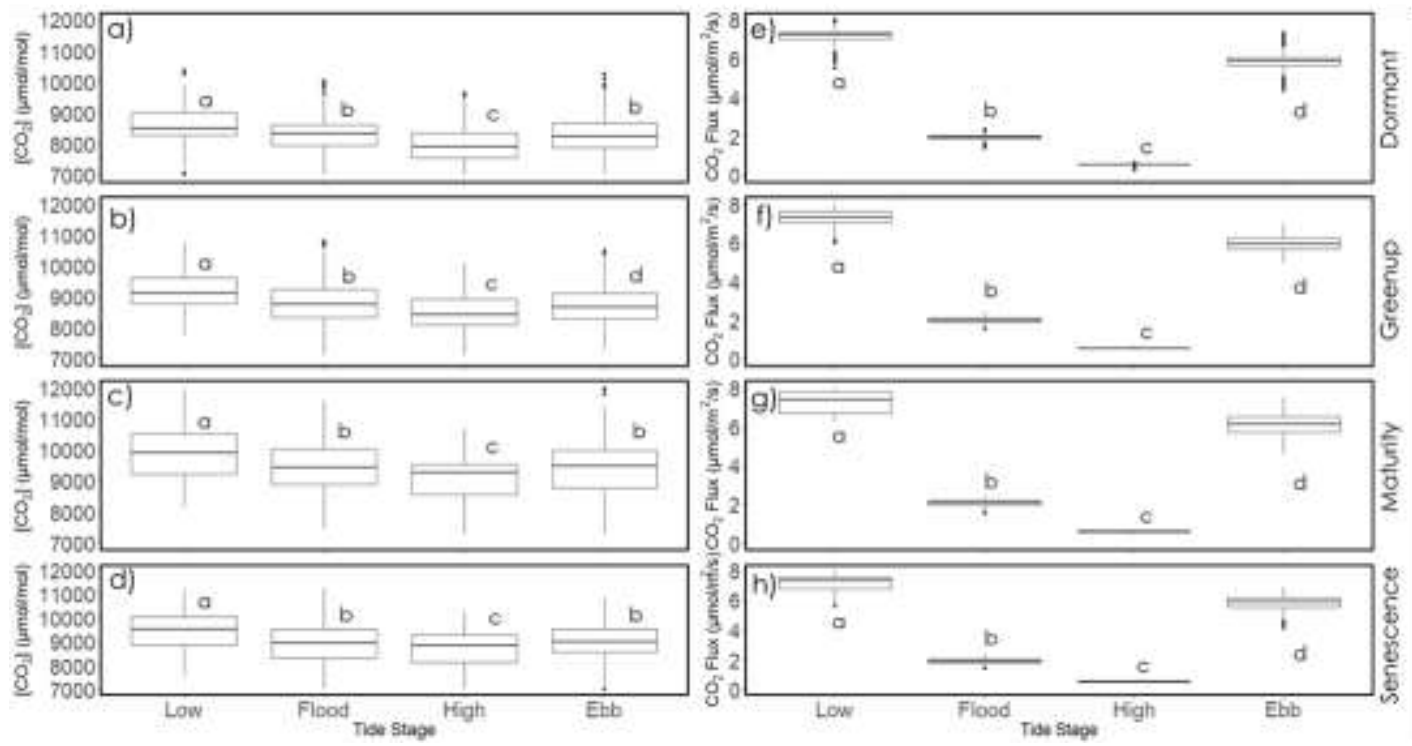

Figure 4 Box plots comparing $\mathrm{CO}_{2}$ concentration (a-d) or $\mathrm{CO}_{2}$ flux (e-h) between tide stages for each phenophase: Dormant (a, e), Greenup (b, f), Maturity (c, g), and Senescence (d, h). Different letters located above or below each box plot represent statistical significance $(\mathrm{p}<0.05)$ among values in that panel.

Daily averages of $\mathrm{pCH}_{4}$ in the creek $(2100 \pm 782.9 \mu \mathrm{mol} / \mathrm{mol})$ exhibited a seasonal trend with a peak in the Maturity phenophase and then declined at a slower rate than it peaked (Figure 3c). Half-hourly averages of $\mathrm{pCH}_{4}$ also demonstrated a slight trend of being highest at high tide $(2180 \pm 840 \mu \mathrm{mol} / \mathrm{mol})$, lowest at low tide $(1900 \pm 7.4 \mu \mathrm{mol} / \mathrm{mol})$, and roughly equal between flood $(2130 \pm 898 \mu \mathrm{mol} / \mathrm{mol})$ and ebb tides $(2020 \pm 708 \mu \mathrm{mol} / \mathrm{mol})$ with slight differences in trends between phenophases (Figure 5a-d). Daily averages of modelled $\mathrm{CH}_{4}$ efflux $(17.4 \pm 6.9$ $\mathrm{nmol} / \mathrm{m}^{2} / \mathrm{s}$ ) held a similar seasonal pattern to $\mathrm{pCH} 4$ albeit with a lower peak (Figure 
3d). Half-hourly averages of modelled creek $\mathrm{CH}_{4}$ emissions were consistently more variable at low tide $\left(48.5 \pm 17.1 \mathrm{nmol} / \mathrm{m}^{2} / \mathrm{s}\right)$ than high tide $\left(2.13 \pm 0.78 \mathrm{nmol} / \mathrm{m}^{2} / \mathrm{s}\right)$ (Figure 5e-h).
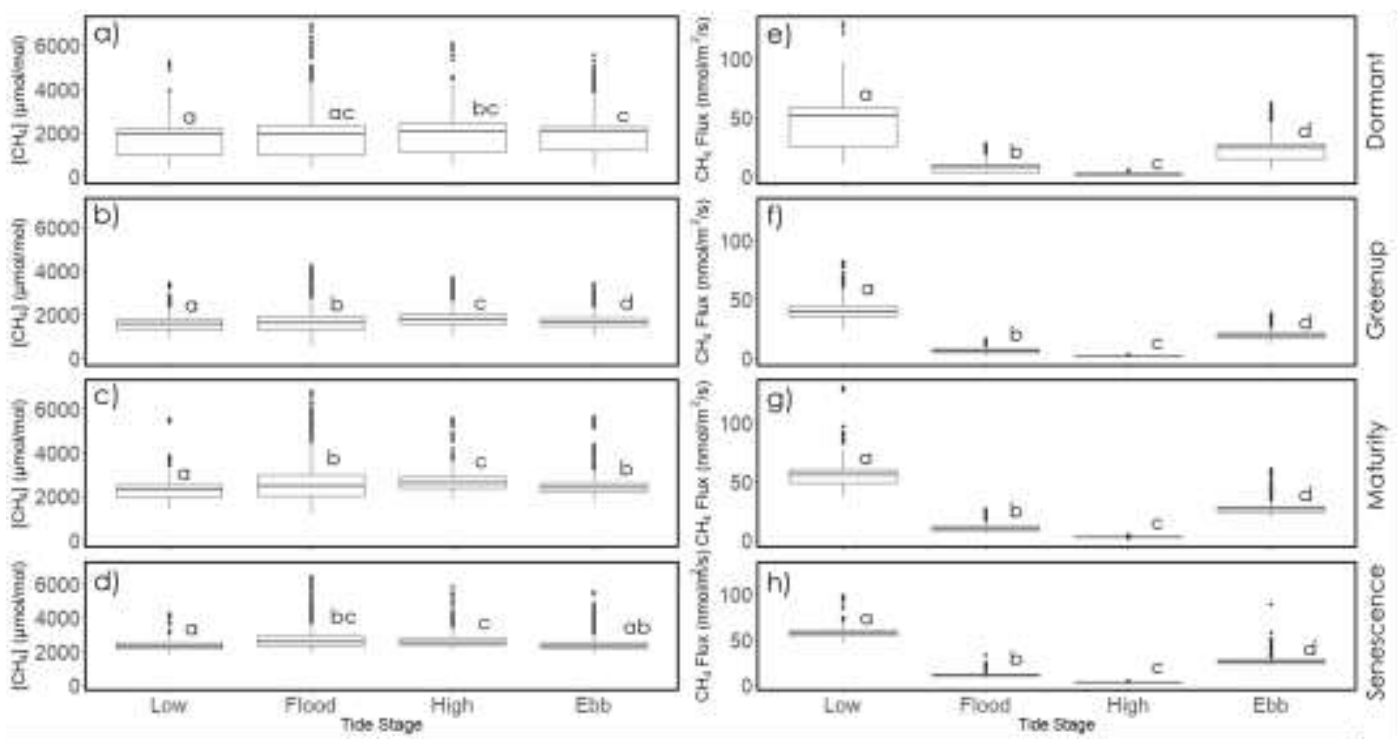

Figure 5 Box plots comparing $\mathrm{pCH}_{4}(\mathrm{a}-\mathrm{d})$ or $\mathrm{CH}_{4}$ efflux (e-h) between tide stages for each phenophase: Dormant (a, e), Greenup (b, f), Maturity (c, g), and Senescence $(\mathrm{d}, \mathrm{h})$. Different letters above each box plot represent statistical significance $(\mathrm{p}<0.05)$ among values in that panel.

Statistically significant relationships $(\mathrm{CCA} ; \mathrm{p}<0.05)$ were found between the daily averages of independent variables and modelled GHG efflux during the whole growing season and within each phenophase save for Senescence (due to data gaps). 
During the whole growing season, the CCA showed that dissolved oxygen and wind speed held notable, hereby defined as a statistically significant correlation coefficient $>|0.4|$, negative correlations with creek $\mathrm{CH}_{4}$ efflux (Figure 6a). Across phenophases, dissolved oxygen remained a notable factor for creek $\mathrm{CH}_{4}$ efflux except during the Maturity phenophase (Figure 6b-d), and wind speed remained a notable factor for $\mathrm{CH}_{4}$ efflux only during the Dormant phenophase (Figure 6b). Salinity emerged as a notable factor for $\mathrm{CH}_{4}$ efflux during the Dormant and Greenup phenophases, solar radiation only during the Dormant phenophase, and temperature only during the Greenup phenophase (Figure 6b-c). During the Dormant phenophase, dissolved oxygen, wind speed, solar radiation, and salinity were also notable factors for $\mathrm{CO}_{2}$ efflux (Figure 6b). During the Maturity phenophase, turbidity was the only variable notably associated with either GHG (Figure 6d). No notable correlations between any independent variables and creek $\mathrm{CO}_{2}$ efflux for the whole growing season were found (Figure 6a). 


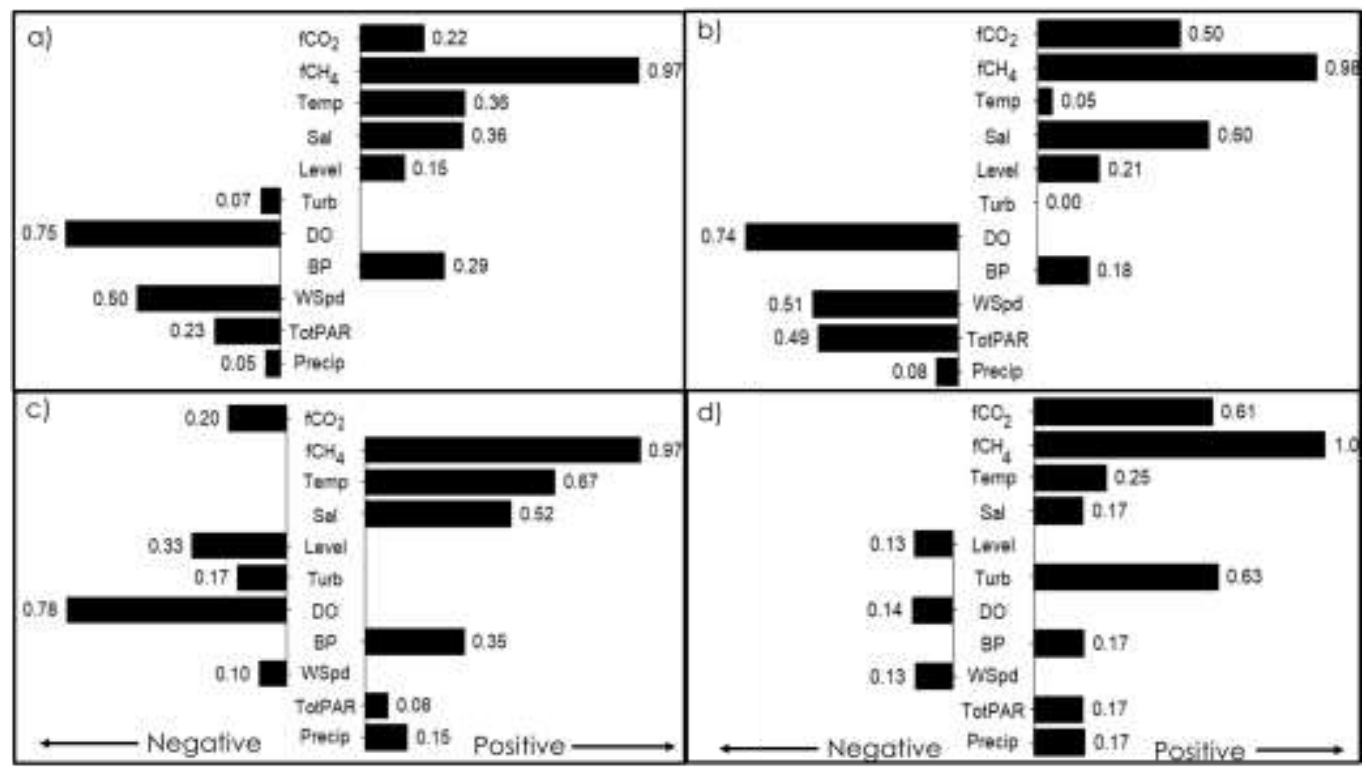

Figure 6 Results of a canonical correlation analysis (CCA) between measured environmental variables and modelled creek $\mathrm{CO}_{2}$ and $\mathrm{CH}_{4}$ efflux during the whole growing season (a), Dormant phenophase (b), Greenup phenophase (c), the Maturity phenophase (d). The Senescence phenophase was found to not have any statistically significant relationships between factors $(p>0.05)$. Numbers represent the linear correlation coefficients between factors with negative correlation coefficients going to the left and positive correlation coefficients going to the right. $\mathrm{fCO}_{2}$ is $\mathrm{CO}_{2}$ efflux $\left(\mu \mathrm{mol} / \mathrm{m}^{2} / \mathrm{s}\right), \mathrm{fCH}_{4}$ is $\mathrm{CH}_{4}$ efflux $\left(\mathrm{nmol} / \mathrm{m}^{2} / \mathrm{s}\right)$, Temp is water temperature $\left({ }^{\circ} \mathrm{C}\right)$, Sal is salinity $(\mathrm{ppt})$, Level is water level (m), Turb is turbidity (NTU), DO is dissolved oxygen $(\mathrm{mg} / \mathrm{l}), \mathrm{BP}$ is barometric pressure $(\mathrm{mb})$, WSpd is wind speed $(\mathrm{m} / \mathrm{s})$, TotPAR is total photosynthetically active radiation $\left(\mathrm{mmol} / \mathrm{m}^{2}\right)$, and Precip is precipitation $(\mathrm{mm})$.

Statistically significant differences were found between ecosystem-scale, creek, and sediment efflux within each phenophase for $\mathrm{CO}_{2}$ and between ecosystem and creek efflux within each phenophase for $\mathrm{CH}_{4}$ (Figure 7, ANOVA; $\left.\mathrm{p}<0.05\right)$. Only $\mathrm{CO}_{2}$ efflux measurements (for sediment and creek) taken at night-time were 
considered for comparison with nighttime ecosystem-scale $\mathrm{CO}_{2}$ efflux measurements (NEE). During the whole year, night-time creek $\mathrm{CO}_{2}$ efflux $\left(3.6 \pm 0.63 \mu \mathrm{mol} / \mathrm{m}^{2} / \mathrm{s}\right)$ was significantly higher than nighttime sediment efflux $\left(1.5 \pm 1.23 \mu \mathrm{mol} / \mathrm{m}^{2} / \mathrm{s}\right)$ but lower than nighttime NEE $\left(5.4 \pm 3.9 \mu \mathrm{mol} / \mathrm{m}^{2} / \mathrm{s}\right)$. However, during the Dormant period, night-time creek $\mathrm{CO}_{2}$ efflux $\left(3.7 \pm 0.45 \mu \mathrm{mol} / \mathrm{m}^{2} / \mathrm{s}\right)$ was higher than both night-time sediment efflux $\left(0.95 \pm 0.81 \mu \mathrm{mol} / \mathrm{m}^{2} / \mathrm{s}\right)$ and NEE $\left(2.1 \pm 1.1 \mu \mathrm{mol} / \mathrm{m}^{2} / \mathrm{s}\right)$. Creek $\mathrm{CH}_{4}$ efflux $\left(17.5 \pm 6.9 \mathrm{nmol} / \mathrm{m}^{2} / \mathrm{s}\right)$ was consistently lower than ecosystem-scale $\mathrm{CH}_{4}$ efflux $\left(68.1 \pm 52.3 \mathrm{nmol} / \mathrm{m}^{2} / \mathrm{s}\right)$ across the whole growing season, with the gap between the two widening as the season progressed. 

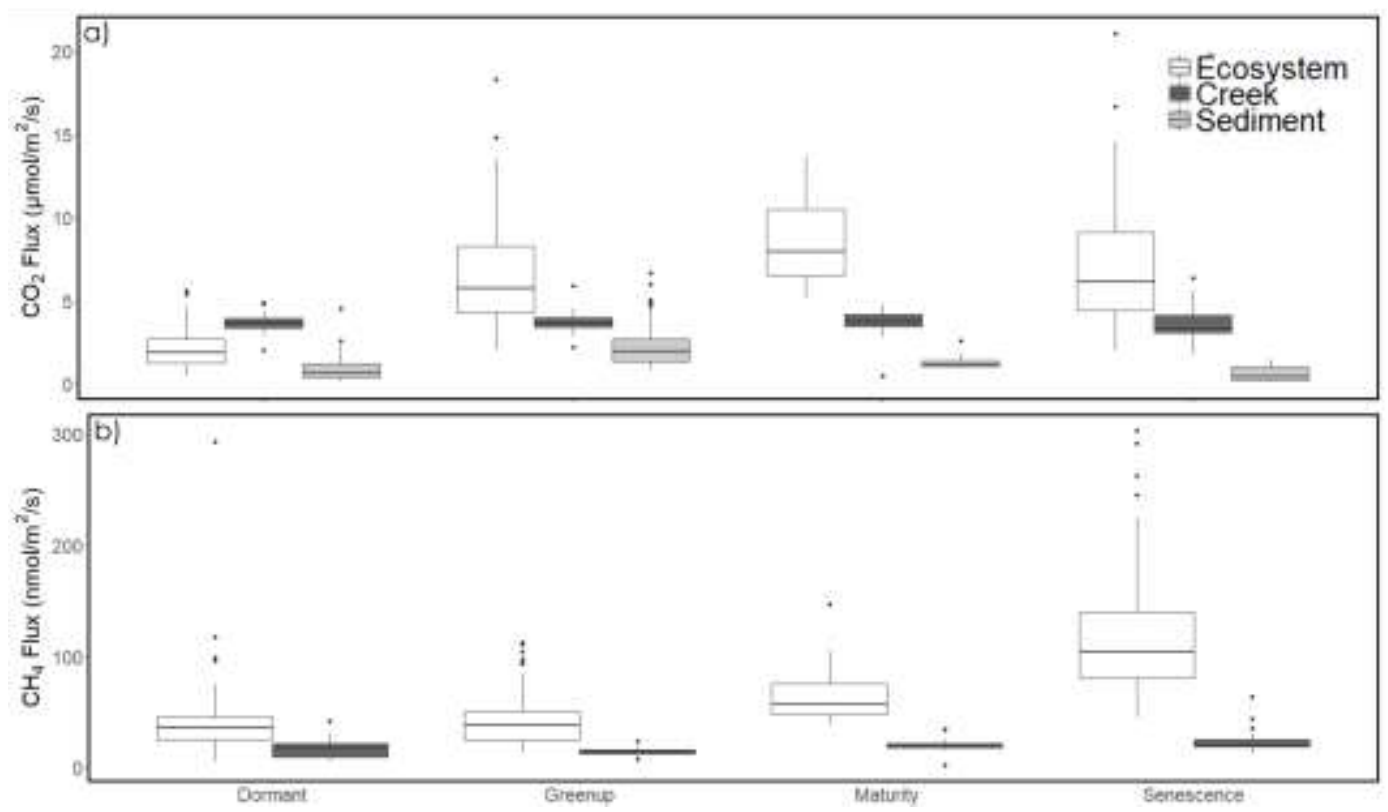

Figure 7 Box plots comparing ecosystem-scale $\mathrm{CO}_{2}$ efflux (nighttime NEE), creek nighttime $\mathrm{CO}_{2}$ efflux, and nighttime sediment $\mathrm{CO}_{2}$ efflux (a). Box plots comparing ecosystem-scale and creek $\mathrm{CH}_{4}$ fluxes (b). Box plots are arranged based on each phenophase. All box plots within each phenophase were significantly different from each other $(\mathrm{p}<0.05)$. Sediment $\mathrm{CH}_{4}$ efflux was not measured.

\section{Discussion}

The first hypothesis, that GHG efflux from the creek would peak in the summer, was supported for $\mathrm{CH}_{4}$ but not for $\mathrm{CO}_{2}$ as the creek lacked significant seasonal variability for $\mathrm{CO}_{2}$ efflux but showed some seasonal variability for $\mathrm{CH}_{4}$ efflux (Figure 3). This differs from observations in temperate terrestrial environments such as forests where both $\mathrm{CO}_{2}$ and $\mathrm{CH}_{4}$ emissions exhibited strong seasonal trends driven by changing temperatures (Yvon-Durocher et al., 2012, 2014). Inland 
temperate aquatic environments like rivers have also exhibited seasonal trends in $\mathrm{CO}_{2}$ efflux (Laruelle et al., 2015). However, the concentrations of both GHGs in the creek did exhibit more of a seasonal pattern than the efflux (Figure 3). The lack of a seasonal trend for GHG efflux compared to the concentrations suggests the influence of confounding and competing factors beyond the concentration gradient between water and air. These factors were tidally linked, likely influencing the gas transfer velocity ( $k$; see below), as the efflux of both GHGs differed markedly by tidal stage (Figures 45). Both GHG effluxes also lacked the expected high correlations with water temperature (Figure 6), suggesting that creek GHG efflux has drivers that are fundamentally different from those of inland terrestrial and aquatic ecosystems. This lack of temperature dependency should be tested across other salt marsh creeks but if it proves to be persistent, then this could be an important mathematical and conceptual formulation for ecosystem-process models across terrestrial-aquatic interfaces.

The influence of tides may explain why the second hypothesis (that ebb and flood tides would have the highest GHG efflux) was only partially supported. One relevant tidal factor is likely water velocity changing with tide stage. Water velocity has been observed to increase the gas transfer velocity $(k)$ of air-water gas efflux in terrestrial streams (Raymond et al., 2012). A higher $k$ during flood and ebb tides may explain why there is a higher GHG efflux during those tide stages. Many tidal channels also experience tidal asymmetry between ebb and flood tides (Pethick, 1980) where one stage has a faster velocity than the other. This tidal asymmetry in velocity may explain the observed difference in flux magnitude between ebb and flood tides 
(Figures 2-4). However, low tide exhibited higher mean efflux than both ebb and flood tide despite its slower velocity. Thus, turbulence may be an additional tidal factor that affects GHG efflux in tidal creeks. As water level falls in a tidal channel, more flow is directed along the channel axis, rather than across, which generates higher turbulence between the creek bed and the water body (Ralston \& Stacey, 2006). Laboratory experiments have demonstrated that increased turbulence at the bottom of a water body increases the $k$ at the surface (Herlina \& Jirka, 2008). At low tide, the creek surface is also much closer to the creek bed and thus the surface $k$ may be more sensitive to turbulence changes at the creek bed. This suggests velocity-based GHG efflux models, as typical for inland streams, will not be accurate for tidal creeks without taking turbulence into account.

The canonical correlation analysis (CCA) allowed us to explore the third hypothesis, that dissolved oxygen and salinity would inhibit $\mathrm{CH}_{4}$ efflux, at the annual scale and by phenophase. Dissolved oxygen had a negative effect on $\mathrm{CH}_{4}$ efflux at the annual scale, but also during the Dormant and Greenup phenophases (Figure 6). These relationships were expected due to the inhibiting effect of oxygen on methanogenesis (Poffenbarger et al., 2011; Tobias \& Neubauer, 2009). At the annual scale, wind speed was also an important factor as higher wind speeds can produce more turbulence, aerate the water surface and thus bring more dissolved oxygen into streams (Chu \& Jirka, 2003; Gualtieri, et al., 2002). Salinity showed a positive relationship with $\mathrm{CH}_{4}$ efflux during the Dormant and Greenup phenophases and no notable relationships at the annual scale or for any other phenophase. This contrasts with the expected 
negative relationship that has been observed in salinity gradient studies and between salt marshes with differing salinity ranges (Bartlett et al., 2016; Poffenbarger et al., 2011). This apparent contradiction could be explained by the temporal variability of salinity within the creek being smaller in magnitude compared to the spatial variability within and between salt marshes. Despite previous studies having found a strong relationship between temperature and soil $\mathrm{CH}_{4}$ efflux (Westermann, 1993; YvonDurocher et al., 2014), our results only supported these observations during the Greenup phenophase. This may be due to tides having a strong influence on $k$, which in turn is a stronger control on creek $\mathrm{CH}_{4}$ efflux than temperature influence.

$\mathrm{CO}_{2}$ efflux also lacked its expected temperature relationship, likely for the same reason as $\mathrm{CH}_{4}$ efflux, as the CCA showed no notable correlations for $\mathrm{CO}_{2}$ efflux at the annual scale (Figure 6). However, during the Dormant phenophase, dissolved oxygen, wind speed, solar radiation, and salinity were notable drivers for $\mathrm{CO}_{2}$ efflux. Both GHG effluxes also had high correlations with each other and the aforementioned drivers (Figure 6). Thus, the relevant drivers for $\mathrm{CO}_{2}$ efflux may have emerged due to this positive relationship with $\mathrm{CH}_{4}$ efflux. Both $\mathrm{GHG}$ effluxes also held positive relationships with each other and turbidity during the Maturity phenophase. The turbidity relationship may represent a pulse of sediments and GHGs entering the creek from the banks with the two events of water level rise seen during the Maturity phenophase (Figure 1). These results bring attention to the potential challenges of modeling GHG fluxes from tidal creeks since there appear to be confounding and competing factors for $\mathrm{CH}_{4}$ efflux and no clear dominant factors for $\mathrm{CO}_{2}$ efflux. 
Identifying consistent key drivers for soil $\mathrm{CO}_{2}$ and $\mathrm{CH}_{4}$ efflux under non-stationary conditions (e.g., during wetting-drying and freezing-thawing cycles) has also be proven to be challenging (Kim et al, 2012). Thus, there is a need to provide more information regarding GHGs pulses and trends across terrestrial and aquatic environments.

Nighttime creek $\mathrm{CO}_{2}$ efflux was higher than nighttime sediment and ecosystem-scale $\mathrm{CO}_{2}$ efflux (i.e., nighttime NEE), thus supporting the fourth hypothesis that the creek was a hotspot for $\mathrm{CO}_{2}$ efflux. Our results support previous observations on point measurements of GHG efflux across different flowing waters of coastal wetlands but expand upon these observations by comparing automated measurements across water, sediments and the ecosystem-scale. For example, a river flowing through a salt marsh was found to have higher $\mathrm{CO}_{2}$ emissions but slightly lower $\mathrm{CH}_{4}$ emissions than the bare soil or marsh plants (Yang et al., 2017). The tidal creeks of mangroves have also shown high concentrations of $\mathrm{pCO}_{2}$ and $\mathrm{pCH}_{4}(\mathrm{Call}$ et al., 2015; Linto et al., 2014), but diffusivity constants (i.e., $k$ ) need to be developed to quantify the effective water-to-atmosphere efflux from these surfaces. Furthermore, this study builds on the evidence that inland streams and rivers have large $\mathrm{CO}_{2}$ emissions globally $\left(1.8 \mathrm{pG} \mathrm{CO}_{2} / \mathrm{yr}\right)$ relative to their surrounding ecosystems (Lauerwald et al., 2009; Raymond et al., 2013) by suggesting that tidal creeks are also emission hotspots within their respective ecosystems. Therefore, it is critical to 
constrain the magnitude of water-to-atmosphere fluxes to reduce the large uncertainties in the carbon cycle associated to tidal wetlands (Hayes et al., 2018).

We postulate that higher $\mathrm{CO}_{2}$ efflux at the creek may be due to lateral transport of $\mathrm{CO}_{2}$ from the creek bank (i.e., sediments that get exposed during low tide) into the creek water (as a physical process driven by the tidal patterns) that increases the water-atmosphere $\mathrm{CO}_{2}$ gradient (Koné \& Borges, 2008). Of note is that creek $\mathrm{CO}_{2}$ efflux during the Dormant period was disproportionately high, having a higher mean than ecosystem-scale $\mathrm{CO}_{2}$ efflux. It is likely that lateral transport of $\mathrm{CO}_{2}$ from sediments to the creek waters (promoted by tidal patterns) is persistent throughout the year and maintains high $\mathrm{CO}_{2}$ concentrations and emissions from the tidal creek. The overall ecosystem $\mathrm{CO}_{2}$ efflux (i.e., nighttime NEE) decreased during the Dormant period likely due to low S. alterniflora root respiration (Teal \& Kanwisher, 1966) from plant senescence, and low microbial heterotrophic respiration from lower temperatures (Yvon-Durocher et al., 2012; Zhang et al., 2013). Therefore, we propose that the influence of physical processes driven by tidal patterns should be included in processbased models for tidal salt marshes and should be taken into consideration when partitioning eddy covariance NEE into gross primary production and ecosystem respiration.

Tides can also promote the lateral transport of $\mathrm{CH}_{4}$ stored in sediments to the creek. It has been reported that sediments at our study site can have $\mathrm{CH}_{4}$ concentrations >50,000 $\mu \mathrm{mol} / \mathrm{mol}$ (Bothfield, 2016; Capooci et al, unpublished), so they can also be a source of $\mathrm{CH}_{4}$ to the tidal creek. It was not uncommon to measure 
$\mathrm{CH}_{4}$ concentrations at $2000 \mu \mathrm{mol} / \mathrm{mol}$ (and up to $>6000 \mu \mathrm{mol} / \mathrm{mol}$ ) within the creek, so this opens the following question: where does this $\mathrm{CH}_{4}$ go? We postulate that tides promote lateral transport of $\mathrm{CH}_{4}$ stored in sediments of salt marshes to the coastal ocean. This has been suggested as a mechanism for $\mathrm{CH}_{4}$ transport in the North Sea of Germany from surrounding tidal flats (Osudar et al., 2015). This hypothesis must be tested across tidal ecosystems around the world.

Finally, the insights gained into the tidal processes affecting creek GHG efflux and its relationship to ecosystem-scale and sediment GHG fluxes would not be possible without high-temporal resolution using automated measurements. Manual measurements can often miss rapid changes in ecological variables like dissolved oxygen (Banas et al., 2005) so automated measurements have been touted to help resolve uncertainties in sediments of salt marshes (Capooci et al., 2019), ecological and carbon cycle models (Hamilton et al., 2014; Vargas et al., 2010). However, manual GHG flux measurements are urgently needed to understand the spatial variability and magnitudes of GHG fluxes across different landscape features of tidal salt marshes around the world. Only a synergistic effort across the scientific 
community will provide the much-needed information to accurately account for the contribution of wetlands to the global carbon cycle. 


\section{CONCLUSIONS}

This study offered unprecedented information of GHG dynamics in a tidal creek using high-temporal resolution automated measurements. Both GHG effluxes from the creek did not exhibit the expected strong temperature-driven seasonal trend, with $\mathrm{CO}_{2}$ efflux having no trend and $\mathrm{CH}_{4}$ efflux having a moderate one. We postulate that the physical effects of tidal changes (velocity, turbulence) overshadows the influence of water temperature in determining magnitudes of GHG efflux. Dissolved oxygen exhibited a negative relationship with $\mathrm{CH}_{4}$ efflux, as expected, while salinity did not due to confounding factors. $\mathrm{CO}_{2}$ efflux had no consistent drivers across the year, suggesting it will be difficult to model and predict throughout the year. The creek exhibited two times higher $\mathrm{CO}_{2}$ efflux than the sediments and made up around $66 \%$ of the overall $\mathrm{CO}_{2}$ emissions from the marsh, suggesting creeks are $\mathrm{CO}_{2}$ emission hotspots within the salt marsh landscape. We postulate that tidal patterns influence the lateral transport of marsh sediment $\mathrm{CO}_{2}$ and $\mathrm{CH}_{4}$ into the creek water, and because of the supersaturation of $\mathrm{pCO}_{2}$ and $\mathrm{pCH}_{4}$ in the water, there is likely a lateral transport to the coastal ocean. The dynamics of GHG fluxes in tidal marshes are regulated in a fundamentally different way than from terrestrial ecosystems; thus, future ecosystemprocess based models should evaluate current assumptions to improve the representation of terrestrial-aquatic interfaces. 


\section{REFERENCES}

Banas, D., Grillas, P., Auby, I., Lescuyer, F., Coulet, E., Moreteau, J. C., \& Millet, B. (2005). Short time scale changes in underwater irradiance in a wind-exposed lagoon ( Vaccarès lagoon, France ): Efficiency of infrequent field measurements of water turbidity or weather data to predict irradiance in the water column, 551(1), 3-16.

Bartlett, K. B., Bartlett, D. S., Harriss, R. C., Sebacher, D. I., Biogeochemistry, S., \& Sebacher, D. I. (2016). Methane Emissions along a Salt Marsh Salinity Gradient Published by : Springer Stable URL : http://www.jstor.org/stable/1468663 REFERENCES Linked references are available on JSTOR for this article : You may need to $\log$ in to JSTOR to access the linked ref, 4(3), 183-202.

Baumann, H., Wallace, R. B., Tagliaferri, T., \& Gobler, C. J. (2015). Large Natural pH, CO 2 and O 2 Fluctuations in a Temperate Tidal Salt Marsh on Diel , Seasonal, and Interannual Time Scales, 220-231. https://doi.org/10.1007/s12237-014-9800-y

Bond-lamberty, B., Bailey, V. L., Chen, M., Gough, C. M., \& Vargas, R. (2018). recent decades. Nature. https://doi.org/10.1038/s41586-018-0358-x

Call, M., Maher, D. T., Santos, I. R., Ruiz-Halpern, S., Mangion, P., Sanders, C. J., ... Eyre, B. D. (2015). Spatial and temporal variability of carbon dioxide and methane fluxes over semi-diurnal and spring-neap-spring timescales in a 
mangrove creek. Geochimica et Cosmochimica Acta, 150, 211-225.

https://doi.org/10.1016/j.gca.2014.11.023

Chmura, G. L., Anisfeld, S. C., Cahoon, D. R., \& Lynch, J. C. (2003). Global carbon sequestration in tidal, saline wetland soils. Global Biogeochemical Cycles, 17(4), n/a-n/a. https://doi.org/10.1029/2002GB001917

Chmura, G. L., Kellman, L., \& Guntenspergen, G. R. (2011). The greenhouse gas flux and potential global warming feedbacks of a northern macrotidal and microtidal salt marsh. Environmental Research Letters, 6(4), 044016.

https://doi.org/10.1088/1748-9326/6/4/044016

Chu, C. R., Jirka, G. H., \& Asce, F. (2003). Wind and Stream Flow Induced Reaeration, 129(December), 1129-1136.

Fagherazzi, S., Wiberg, P. L., Temmerman, S., Struyf, E., Zhao, Y., \& Raymond, P. a. (2013). Fluxes of water, sediments, and biogeochemical compounds in salt marshes. Ecological Processes, 2(1), 3. https://doi.org/10.1186/2192-1709-2-3

Filippa, G., Cremonese, E., Migliavacca, M., Galvagno, M., Forkel, M., Wingate, L., ... Richardson, A. D. (2016). Phenopix: A R package for image-based vegetation phenology. Agricultural and Forest Meteorology, 220, 141-150. https://doi.org/10.1016/j.agrformet.2016.01.006

Forbrich, I., \& Giblin, A. E. (2015). Marsh-atmosphere CO2exchange in a New 
England salt marsh. Journal of Geophysical Research G: Biogeosciences, 120(9), 1825-1838. https://doi.org/10.1002/2015JG003044

Forbrich, I., Giblin, A. E., \& Hopkinson, C. S. (2018). Constraining Marsh Carbon Budgets Using Long-Term C Burial and Contemporary Atmospheric CO2Fluxes. Journal of Geophysical Research: Biogeosciences, 123(3), 867-878. https://doi.org/10.1002/2017JG004336

Gillespie, A. R., Kahle, A. B., \& Walker, R. E. (1987). Color Enhancement of Highly Correlated Images . II . Channel Ratio and " Chromaticity " Transformation Techniques, 365, 343-365.

Gualtieri, C., Gualtieri, P., \& Doria, G. P. (2002). Dimensional Analysis of Reaeration Rate in Streams, 128(January), 12-18.

Hadley, S., Tang, M. J., \& Street, M. B. L. (2015). Salt Marsh Restoration : Changes in Greenhouse Gas Flux Nia Bartolucci.

Hamilton, D. P., Carey, C. C., Arvola, L., Arzberger, P., Cole, J. J., Gaiser, E., ... Lin, F. (2015). A Global Lake Ecological Observatory Network ( GLEON ) for synthesising high-frequency sensor data for validation of deterministic ecological models A Global Lake Ecological Observatory Network ( GLEON) for synthesising high-frequency sensor data for validation of deterministic ecological models, 2041. https://doi.org/10.5268/IW-5.1.566 
Herlina, \& Jirka, G. H. (2008). Experiments on gas transfer at the air-water interface induced by oscillating grid turbulence. Journal of Fluid Mechanics, 594, $183-$ 208. https://doi.org/10.1017/S0022112007008968

Howard, J., Sutton-Grier, A., Herr, D., Kleypas, J., Landis, E., Mcleod, E., ... Simpson, S. (2017). Clarifying the role of coastal and marine systems in climate mitigation. Frontiers in Ecology and the Environment, 15(1), 42-50. https://doi.org/10.1002/fee.1451

Huertas, I. E., Flecha, S., Figuerola, J., Costas, E., \& Morris, E. P. (2017). Effect of hydroperiod on $\mathrm{CO}_{2}$ fluxes at the air-water interface in the Mediterranean coastal wetlands of Doñana. Journal of Geophysical Research: Biogeosciences, 16151631. https://doi.org/10.1002/2017JG003793

Jones, S. F., Stagg, C. L., Krauss, K. W., \& Hester, M. W. (2018). Flooding Alters Plant-Mediated Carbon Cycling Independently of Elevated Atmospheric CO2Concentrations. Journal of Geophysical Research: Biogeosciences, 123(6), 1976-1987. https://doi.org/10.1029/2017JG004369

Kirwan, M. L., Guntenspergen, G. R., \& Langley, J. A. (2014). Temperature sensitivity of organic-matter decay in tidal marshes. Biogeosciences, 11(17), 4801-4808. https://doi.org/10.5194/bg-11-4801-2014

Koné, Y. J. M., \& Borges, A. V. (2008). Dissolved inorganic carbon dynamics in the waters surrounding forested mangroves of the Ca Mau Province (Vietnam). 
Estuarine, Coastal and Shelf Science, 77(3), 409-421.

https://doi.org/10.1016/j.ecss.2007.10.001

Laruelle, G. G., Lauerwald, R., Rotschi, J., Raymond, P. A., Hartmann, J., \& Regnier, P. (2015). Seasonal response of air - water CO 2 exchange along the land - ocean aquatic continuum of the northeast North American coast ., 1447-1458. https://doi.org/10.5194/bg-12-1447-2015

Linto, N., Barnes, J., Ramachandran, R., Divia, J., Ramachandran, P., \& UpstillGoddard, R. C. (2014). Carbon Dioxide and Methane Emissions from MangroveAssociated Waters of the Andaman Islands, Bay of Bengal. Estuaries and Coasts, 37(2), 381-398. https://doi.org/10.1007/s 12237-013-9674-4

Macreadie, P. I., Hughes, A. R., \& Kimbro, D. L. (2013). Loss of “Blue Carbon” from Coastal Salt Marshes Following Habitat Disturbance. PLoS ONE, 8(7), 1-8. https://doi.org/10.1371/journal.pone.0069244

McLeod, E., Chmura, G. L., Bouillon, S., Salm, R., Björk, M., Duarte, C. M., ... Silliman, B. R. (2011). A blueprint for blue carbon: Toward an improved understanding of the role of vegetated coastal habitats in sequestering $\mathrm{CO} 2$. Frontiers in Ecology and the Environment, 9(10), 552-560. https://doi.org/10.1890/110004

Moffett, K. B., Wolf, A., Berry, J. A., \& Gorelick, S. M. (2010). Salt marshatmosphere exchange of energy, water vapor, and carbon dioxide: Effects of tidal 
flooding and biophysical controls. Water Resources Research, 46(10), 1-18. https://doi.org/10.1029/2009WR009041

Moseman-valtierra, S., \& Moseman-valtierra, S. (2012). R ECONSIDERING C LIMATIC R OLES OF M ARSHES : A RE THEY S INKS OR S OURCES OF G REENHOUSE G ASES?

Neubauer, S. C., \& Anderson, I. C. (2003). Transport of dissolved inorganic carbon from a tidal freshwater marsh to the York River estuary. Limnology and Oceanography, 48(1), 299-307.

Osudar, R., Matou, A., Alawi, M., Wagner, D., \& Bussmann, I. (2015). Environmental factors affecting methane distribution and bacterial methane oxidation in the German Bight (North Sea). Estuarine, Coastal and Shelf Science, 160, 10-21. https://doi.org/10.1016/j.ecss.2015.03.028

Pearson, A. J., Pizzuto, J. E., \& Vargas, R. (2016). Geoderma In fl uence of run of river dams on fl oodplain sediments and carbon dynamics. Geoderma, 272, 5163. https://doi.org/10.1016/j.geoderma.2016.02.029

Pendleton, L., Donato, D. C., Murray, B. C., Crooks, S., Jenkins, W. A., Sifleet, S., ... Baldera, A. (2012). Estimating Global "Blue Carbon” Emissions from Conversion and Degradation of Vegetated Coastal Ecosystems. PLoS ONE, 7(9). https://doi.org/10.1371/journal.pone.0043542 
Pethick, J. S. (1980). Velocity surges and asymmetry in tidal channels. Estuarine and Coastal Marine Science, 11(3), 331-345. https://doi.org/10.1016/S0302$3524(80) 80087-9$

Poffenbarger, H. J., Needelman, B. A., \& Megonigal, J. P. (2011). Salinity Influence on Methane Emissions from Tidal Marshes, 831-842. https://doi.org/10.1007/s13157-011-0197-0

Ralston, D. K., \& Stacey, M. T. (2006). Shear and turbulence production across subtidal channels, 147-171.

Raymond, P. A., Hartmann, J., Lauerwald, R., Sobek, S., McDonald, C., Hoover, M., ... Guth, P. (2013). Global carbon dioxide emissions from inland waters. Nature, 503(7476), 355-359. https://doi.org/10.1038/nature12760

Raymond, P. A., Zappa, C. J., Butman, D., Bott, T. L., Potter, J., Mulholland, P., ... Newbold, D. (2012). Scaling the gas transfer velocity and hydraulic geometry in streams and small rivers. Limnology and Oceanography: Fluids and Environments, 2(1), 41-53. https://doi.org/10.1215/21573689-1597669

Risk, D., Nickerson, N., Creelman, C., Mcarthur, G., \& Owens, J. (2011). Agricultural and Forest Meteorology Forced Diffusion soil flux : A new technique for continuous monitoring of soil gas efflux. Agricultural and Forest Meteorology, 151(12), 1622-1631. https://doi.org/10.1016/j.agrformet.2011.06.020 
Ruiz-Fernández, A. C., Carnero-Bravo, V., Sanchez-Cabeza, J. A., Pérez-Bernal, L. H., Amaya-Monterrosa, O. A., Bojórquez-Sánchez, S., ... Marmolejo-Rodríguez, A. J. (2018). Carbon burial and storage in tropical salt marshes under the influence of sea level rise. Science of The Total Environment, 630, 1628-1640. https://doi.org/10.1016/j.scitotenv.2018.02.246

Teal, J. M., \& Kanwisher, J. W. (1966). Gas transport in the marsh grass, Spartina alterniflora. Journal of Experimental Botany, 17(2), 355-361. https://doi.org/10.1093/jxb/17.2.355

Tobias, C., \& Neubauer, S. (2009). Chapter 16 - Salt Marsh Biogeochemistry - An Overview. COASTAL WETLANDS: An Integrated Ecosystem Approach (First edit, Vol. 76). Elsevier. https://doi.org/10.1016/B978-0-444-53103-2.00016-8

Tong, C., Wang, W.-Q., Zeng, C.-S., \& Marrs, R. (2010). Methane (CH4) emission from a tidal marsh in the Min River estuary, southeast China. Journal of Environmental Science and Health. Part A, Toxic/Hazardous Substances \& Environmental Engineering, 45(4), 506-16. https://doi.org/10.1080/10934520903542261

Vargas, R., \& Carbone, M. S. (2011). Frontiers and challenges in soil respiration research : from measurements to model-data integration, 1-13. https://doi.org/10.1007/s10533-010-9462-1

Wang, Z. A., \& Cai, W. J. (2004). Carbon dioxide degassing and inorganic carbon 
export from a marsh-dominated estuary (the Duplin River): A marsh CO2 pump. Limnology and Oceanography, 49(2), 341-354.

https://doi.org/10.4319/lo.2004.49.2.0341

Wang, Z. A., Kroeger, K. D., Ganju, N. K., Gonneea, M. E., \& Chu, S. N. (2016). Intertidal salt marshes as an important source of inorganic carbon to the coastal ocean. Limnology and Oceanography, 61(5), 1916-1931.

https://doi.org/10.1002/lno.10347

Warner, D. L., Villarreal, S., Mcwilliams, K., Inamdar, S., \& Vargas, R. (2017). Carbon Dioxide and Methane Fluxes From Tree Stems, Coarse Woody Debris, and Soils in an Upland Temperate Forest. Ecosystems, 20(6), 1205-1216. https://doi.org/10.1007/s10021-016-0106-8

Yang, W. Bin, Yuan, C. S., Tong, C., Yang, P., Yang, L., \& Huang, B. Q. (2017). Diurnal variation of $\mathrm{CO} 2, \mathrm{CH} 4$, and $\mathrm{N} 2 \mathrm{O}$ emission fluxes continuously monitored in-situ in three environmental habitats in a subtropical estuarine wetland. Marine Pollution Bulletin, 119(1), 289-298.

https://doi.org/10.1016/j.marpolbul.2017.04.005

Yvon-Durocher, G., Allen, A. P., Bastviken, D., Conrad, R., Gudasz, C., St-Pierre, A., ... del Giorgio, P. A. (2014). Methane fluxes show consistent temperature dependence across microbial to ecosystem scales. Nature, 507(7493), 488-491. https://doi.org/10.1038/nature13164 
Yvon-Durocher, G., Caffrey, J. M., Cescatti, A., Dossena, M., Giorgio, P. Del, Gasol, J. M., ... Allen, A. P. (2012). Reconciling the temperature dependence of respiration across timescales and ecosystem types. Nature, 487(7408), 472-476. https://doi.org/10.1038/nature11205

Zhong, Q., Du, Q., Gong, J., Zhang, C., \& Wang, K. (2013). Effects of in situ experimental air warming on the soil respiration in a coastal salt marsh reclaimed for agriculture. Plant and Soil, 371(1-2), 487-502.

https://doi.org/10.1007/s11104-013-1707-z 